\title{
A Systematic Analytical Study of certain North American Convallariaceae, considered in regard to their Origin through Discontinuous Variation. ${ }^{1}$
}

\author{
BY
}

\author{
R. RUGGLES GATES, Ph.D., F.L.S.,
}

Sometime Lecturer in the University of London and Professor in the University of California.

$\mathrm{T}$

HE following is a précis of the main points in the original paper, the

full publication of which is reserved until after the War :

The work is a systematic treatment of the Convallariaceae of North America which aims primarily to consider their relationships and phylogeny from the point of view of the mutationist. By analysis of the characters of the various species and genera, it is shown that many of the specific and generic differences are such as may have arisen through marked discontinuous changes. Indeed, many of the differences cannot be reasonably interpreted as the result of the gradual accumulation of smaller differences - the older Darwinian view of evolution. The paper is, therefore, an application to systematic work of the mutationist conceptions gained from experimentation. Its aim is to show how specific differences can be analytically treated in terms of definite and marked variations. It appears that apparently great external changes may be the result of a single germinal alteration, and that related species have often not been gradually differentiated, but have arisen by definite steps and probably in many cases without any aid from Natural Selection.

Many difficulties naturally arise in connexion with this or any other method of explanation, and a number of these difficulties are discussed in the paper.

Since the North American Polygonatums have been very much confused and are not yet well understood, an account of this genus is published elsewhere. $^{2}$ The genus Trillium and its relatives, and the extensive literature on the variations of Trillium, are also treated in another publication. ${ }^{3}$

1 A synopsis of this paper was presented before the Royal Society of Canada, at Ottawa, in May, 19 I 7 , by Dr. A. H. Mackay, Superintendent of Education for Nova Scotia.

2 Gates, R. R. : A Revision of the Genus Polygonalum in North America. Bull. Torr. Bot. Club, vol. xliv, 1917, pp. 117-26, Pls. 1V-VI.

3 A Systematic Study of the North American Genus Trillium, its Variability, and its Relation to Paris and Medeola. Annals, Missouri Bot. Garden, vol. iv, pp. 43-92, Pls. VI-VIII, Map.

[Annals of Botany, Vol. XXXII. No, CXXVI, April, 1918.] 
The term variety has been used in many senses, and it has therefore seemed desirable to draw a distinction between two classes of varieties, although it is not always possible to distinguish clearly between them. The sharply defined variety or varietas abrupta (written var. abr.) is the term used to designate those forms which differ from the type in an abrupt and clearly defined manner, suggesting that they have arisen from the type through a mutation and exhibit a unit-character difference. On the other hand, varieties which exhibit a series of intermediate stages are known as transitional varieties (varietas transitionis, written var. trans.). Although it is not possible to classify all varieties in this way, yet it is deemed useful to make this distinction in certain cases.

The original paper contains a mass of detail, so that only a few selected cases illustrating the point of view can be considered here.

The genus Clintonia contains six species-two in eastern and two in western North America, one in Japan and eastern Siberia, and one in the Himalayas. They are all well-marked species. The differences between C. borealis and C. umbellulata in eastern Canada and the United States have been considered elsewhere. ${ }^{1}$ These two species are the most closely related, differing chiefly in size and number of flowers and the pubescence of the pedicels. There has been relatively little extinction between them, and the steps by which they have diverged have been relatively small. Of the two western species, $C$. uniflora was probably developed from the ancestors of $C$. borealis through a few steps, chiefly retrogressive, in the production of a single white flower.

The other western species, C. Andrewsiana, must have attained its present condition through several well-marked progressive steps: (I) great increase in size, (2) increase in number of flowers, (3) change in flower-colour to rose. All these changes could not have resulted from a single mutation, and hence a considerable amount of extinction must have taken place. A difficulty arises here, for while a stouter mutation might be supposed to triumph over a less robust original condition, yet there is no obvious reason why rose-coloured flowers should replace yellow ones. Breeding experiments and a cytological examination of the four species would help to answer such questions as these.

In forma lateralis, Peck, of the eastern $C$. borealis there are one or two lateral umbels on the scape, in addition to the terminal one. It is significant that this tendency in $C$. borealis is fully expressed in the constantly numerous lateral flower fascicles of $C$. Andrewsiana.

In Smilacina the two eastern species have corresponding western varieties, respectively $S$. racemosa var. trans. amplexicaulis and $S$. stellata var. trans. sessilifolia. Although in the east these two species are relatively fixed and uniform, yet their western varieties show all intergrades to the

\footnotetext{
1 On Pairs of Species. Bot. Gaz., vol. 1xi, 1916, p.181, Figs. 2, 3.
} 
typical eastern forms, indicating that an evolutionary process of some continuous kind is in progress.

The variety $S$. stellata var. mollis (Farwell) comb. nov. is said to differ chiefly ' in having the leaves densely and permanently velvety pubescent all over the lower surface'. The specimens cited are from Michigan and the Black Hills of South Dakota. This pubescent variation is apparently parallel to Maianthemum Canadense var.interius, Fernald, the type of which came also from the arid Black Hills region and which differs from the species in being densely hirsute on the stems and the lower surface of the leaves. This case of a probable mutation which enabled the species to extend its range has been referred to elsewhere. ${ }^{1}$

There are eight recognized species of Disporum in North America, the remaining species being European or Asiatic. The distribution of the American species is roughly as follows: D. lanuginosum, from Ontario to Tennessee; $D$. maculatum, a restricted area in the mountains of Tennessee and North Carolina; D. trachycarpum, from the Canadian prairies south to Colorado and west to Oregon; D. Smithii, in the coast ranges from British Columbia to northern California; D. oregamim, distribution similar to that of $D$. Smithii, but extending farther inland; D. trachyandrum, in the Sierra Nevadas from Oregon to middle California ; D. Hookeri, in a restricted area of the coast range of middle California ; $D$. parvifolium, rare, in the Siskiyou Mountains of northern California.

These species are for the most part rather sharply marked. Nearly all of them are clearly distinguished from another species by one striking difference, accompanied in some cases by other minor differences. The nature of these differences is such as experience teaches us might have arisen through a single mutation. Furthermore, we are familiar in the Oenotheras with mutations in which one character has been markedly modified while others are only slightly altered. Thus $D$. maculatum differs from $D$. lanuginosum chiefly in having somewhat larger flowers, but most strikingly in having the perianth segments yellowish white with fine purple spots, instead of greenish.

Again, D. trachycarpum is sharply distinguished from D. lanuginosum and all other species in having beautifully reticulated fruits, whereas they are glabrous in nearly all other species. D. trachycarpum was considered a variety of $D$. lanuginosum by both Baker and Hooker, and it is by no means unreasonable to suppose that a single mutation may have produced it, though it differs from D. lanuginosum also in having fewer seeds, and stamens as long as the perianth.

$D$. oregamum differs from the eastern species in having an entire instead of a three-cleft stigma, and from its nearest relative, $D$. trachycarpum, in its ovate (not globose) pubescent or glabrous but smooth (not reticulated)

1 The Mutation Theory and the Species-concept. Amer. Naturalist, vol. 1i, 1917, p. $5^{8} 3$. 
fruits; also in certain minor characters of foliage and pubescence. But the two species run into each other and probably intercross.

D. Smithii and D. Hookeri form a pair differing in having respectively, (I) larger whitish and smaller greenish flowers, (2), densely short-hairy or glabrous style and ovary, (3) leaves mostly subcordate or cordate at base ; (4) in D. Smithii the leaf margins are ciliate. D. Hookeri differs from all the others in having flowers which are broad and truncate at base. D.trachyandrum probably originated from $D$. Hookeri through a mutation. It differs strikingly in having hairy anthers, but the leaves are also less deeply cordate and distinctly broader towards the apex, and the ovary is glabrous.

Thus it will be seen that for the most part the species of this genus are sharply separated from each other by 'presence and absence' characters, and only to a minor extent by quantitative characters. The latter are likely to be often merely by-products, as it were, of the more striking germinal changes. It is impossible to suppose that, e. g., stages in the development of the reticulation of the fruit, the lobing of the stigma, or the hairiness of the anthers could be of use to the plant. Indeed, it seems fairly clear that such differences are the result of sudden ' chance variations' and have no significance in the economy of the plant's life. Having appeared, heredity perpetuates them, and so new varieties or species come to be established. Their comparative recency of origin can perhaps be judged to some extent by the relative areas they now occupy. ${ }^{1}$ We should then expect $D$. maculatum and $D$. trachyandrum to have originated relatively recently, while $D$. trachycarpum, which occupies a much wider area, may have originated from $D$. lamuginosum at an earlier time. There are, however, difficulties in applying this view in detail even to such a relatively simple genus as Disporum. But the underlying idea of definite variations arising in certain localities and afterwards spreading, rather than the hypothetical accumulation of small differences and the subsequent elimination of intermediates, corresponds with the facts of such a genus as we observe them. In the light of the facts of mutation, single definite steps, or in some cases a few steps, from species to species are by no means improbable, and it appears that all the conditions in the North American Disporums can be explained by their aid, without resorting to the accumulation hypothesis.

The genus Uvularia is confined to eastern North America. It contains two species, $U$. perfoliata and U. grandiflora, and a third, $U$. flava, which is known only from a figure and description in Smith's 'Exotic Botany', and is probably a hybrid between the other two. Both these species range from Quebec nearly to Florida, but $U$.grandiflora extends farther west into

1 This was originally written before the interesting papers of Willis appeared, applying this conception to the floras of Ceylon and New Zealand.

See Willis, J. C. : The Evolution of Species in Ceylon, with reference to the Dying Out of Species, Annals of Botany, vol. xxx, 1916; The Distribution of Species in New Zealand, ibid., pp. $437-57$; and several other recent papers. 
Kansas and Minnesota. The striking distinctions are in the presence or absence of papillae on the perianth segments, and in the ventral surface of the leaves being glaucous or pubescent. U. grandiflora may possibly be a cell-giant of $U$.perfoliata which has since undergone two or three mutations, such as (I) loss of papillae from the perianth segments and (2) acquiry of pubescence instead of glaucousness.

The genus Oakesia was formerly included in Uvularia, to which it is closely related. It includes four species occupying much the same area as Uvularia. The common ancestor of the two genera probably had the sessile leaves and ovoid fruits of Disporum. One or more mutations produced from this stock the perfoliate leaves of Uvularia, while another series of mutations led to the peculiar winged capsules, angular stem, and other features of Oakesia. The great similarity of the two genera in habit and flowers shows that there has been little extinction between them.

The only other genus to which reference will be made here is Streptopus, in which three American species are recognized. S. amplexifolius and $S$. roseus make an excellent pair of species, as pointed out elsewhere. ${ }^{1}$ $S$. longipes, Fernald, described in 1906, is at present known only from Michigan, New Hampshire, and Campobello Island, New Brunswick. It differs from $S$. roseus chiefly in having trigonous instead of subglobose berries. The flowers may also be paler and the root-stocks longer and more slender, but these are fluctuating and inconstant characters. This form has probably originated from S. roseus through a mutation, and furnishes a very good instance of a germinal change in which the main difference has arisen in one organ, with minor, more or less fluctuating differences in other parts of the plant.

Most of the specific and generic characters considered in this paper as differentiating the members of the Convallariaceae are such as are unlikely to be of any advantage to the plant. They probably appeared as germinal variations, and have since been perpetuated and have enlarged in various directions their area of occupation.

1 On Pairs of Species. Bot. Gaz., vol. 1xi, 1916, p. 185, Figs. 4, 5 . 


\section{$2 \mathrm{BHL}$ Biodiversity Heritage Library}

Gates, R. Ruggles. 1918. "A systematic analytical study of certain North American Convallariaceae, considered in regard to their origin through discontinuous variation." Annals of botany 32, 253-257. https://doi.org/10.1093/oxfordjournals.aob.a089675.

View This Item Online: https://www.biodiversitylibrary.org/item/238284

DOI: https://doi.org/10.1093/oxfordjournals.aob.a089675

Permalink: https://www.biodiversitylibrary.org/partpdf/320218

\section{Holding Institution}

Smithsonian Libraries

\section{Sponsored by}

Biodiversity Heritage Library

\section{Copyright \& Reuse}

Copyright Status: Not in copyright. The BHL knows of no copyright restrictions on this item.

This document was created from content at the Biodiversity Heritage Library, the world's largest open access digital library for biodiversity literature and archives. Visit BHL at https://www.biodiversitylibrary.org. 